\title{
Natural fodder species and analysis for diet pattern in breeding tract of Kathani cattle in Maharashtra
}

\author{
SAJAL KULKARNI, SUREKHA KALE, R.L. BHAGAT, A.B. PANDE AND D.K. KULKARNI
}

\begin{abstract}
Most commonly available fodder species of breeding tract of Kathani cattle in Maharashtra are collected and nutritionally analyzed and found to have protein ranging from 4.73 per cent to 13.39 per cent, fibre from 23.57 per cent to 34.44 per cent, oil from 0.21 per cent to 10.21 per cent. Almost all samples have silica less than 5 per cent. This shows the tremendous variation in locally available fodder species. This also indicate the facts of fodder species available locally which we need to tell the farmers to adjust the feeding quantities according to the nutritional analysis and the availability of the fodder. This small study also shows the importance of forest in raising the cattle population with low inputs at farmers conditions.
\end{abstract}

KEY WORDS : Fodder species, Kathani cattle, Nutritional analysis, Vidarbha region, Maharashtra

How TO CITE THIS PAPER : Kulkarni, Sajal, Kale, Surekha, Bhagat, R.L., Pande, A.B. and Kulkarni, D.K. (2016). Natural fodder species and analysis for diet pattern in breeding tract of Kathani cattle in Maharashtra. Res. J. Animal Hus. \& Dairy Sci., 7(1) : 24-27 : DOI: 10.15740/HAS/ RJAHDS/7.1/24-27.

Address for correspondence :

D.K. Kulkarni, BAIF Development Research Foundation, CRS, Uralikanchan PUNE (M.S.) INDIA

Email : dilipkkulkarni@gmail.com

Associated Authors' :

Sajal Kulkarni, Surekha Kale, R.L. Bhagat and A.B. Pande, BAIF Development Research Foundation, CRS, Uralikanchan PUNE (M.S.) INDIA 